\title{
HUKUM PENGOPERASIAN KAPAL NIRAWAK
}

\author{
Bela Awaliyah Agustina \\ Program Magister Fakultas Hukum, Universitas Indonesia \\ e-mail: belaawaliyah8@gmail.com
}

\begin{abstract}
ABSTRAK
Teknologi terus berkembang hingga mampu menjamah setiap aspek kehidupan manusia. Salah kemajuan teknologi dalam bidang pelayaran saat ini adalah Kapal Tanpa Awak/Nirawak atau yang disebut juga dengan Marine Autonomous Surface Ships (MASS). Meski MASS telah dikembangkan dan digunakan oleh banyak Negara, sampai dengan saat ini belum memiliki regulasi konkret yang mengatur mengenai batasan dan aspek-aspek tertentu dalam kegiatan pengoperasiannya, termasuk UNCLOS sebagai pedoman utama hukum laut. Penelitian ini bertujuan untuk membahas mengenai instrumen hukum yang dapat dijadikan pedoman dalam pengoperasian MASS. Pada Tahun 2019, Henrik Ringbom dalam tulisannya yang berjudul Regulating Autonomous Ships-Concepts, Challenges and Precedents dalam Jurnal Ocean Development \& International Law, membahas mengenai pengaturan MASS yang berfokus pada konsep, tantangan, dan preseden hukum MASS. Berbeda dengan penelitian sebelumnya, penelitian ini membahas mengenai panduan hukum yang bisa digunakan dalam pengoperasian MASS. Penelitian ini menggunakan metode hukum normatif dengan pendekatan perundang-undangan yang digabungkan dengan pendekatan konsep dan sifat penelitian eksploratif yang fokus pada hukum MASS. Hasil dari penelitian ini adalah Pedoman Sementara yang ditetapkan oleh IMO Nomor: MSC.1/Circ.1604 Tahun 2019 menjadi panduan pengoperasian MASS selama regulasi formal belum diterbitkan, dengan tetap mengikuti ketentuan dalam konvensi-konvensi internasional terkait. Diharapkan penelitian ini akan dapat memberikan gambaran yang lebih jelas mengenai panduan dalam pengoperasian MASS sebelum adanya aturan khusus.
\end{abstract}

Kata Kunci: MASS; Kapal; IMO

\section{ABSTRACT}

Technology continues to develop to be able to touch every aspect of human life. One of the technological advances in today's shipping field is Unmanned Ships, also known as Marine Autonomous Surface Ships (MASS). Although MASS has been developed and used by many countries, up to now, there is no concrete regulation that regulates certain limits and aspects of its operational activities, including UNCLOS as the main guideline for the law of the sea. This study aims to discuss legal instruments that can be used as guidelines in the operation of MASS. In 2019, Henrik Ringbom, in his writing entitled Regulating Autonomous Ships-Concepts, Challenges, and Precedents in the Journal of Ocean Development \& International Law, discussed the MASS regulation focusing on the concepts, challenges, and legal precedents of MASS. In contrast to previous research, this study discusses legal guidelines used in the MASS operation. This study uses a normative legal method with a statutory approach combined with a conceptual approach and exploratory research that focuses on MASS law. The results of this research are the Provisional Guidelines set by IMO Number: MSC.1/Circ.1604 Year 2019 to guide the operation of MASS as long as formal regulations have not been issued while still following the provisions of related international conventions. It is hoped that this research will provide a clearer picture of the guidelines in the operation of MASS before the existence of special rules.

Keywords: MASS; Ship; IMO 


\section{PENDAHULUAN}

Kapal Nirawak atau Kapal Tanpa Awak/ Marine Autonomous Surface Ships (MASS) merupakan suatu teknologi dalam bidang pelayaran yang dikembangkan pada kapal. Teknologi yang digunakan untuk menunjang upaya pemanfaatan laut ini memiliki bentuk, ukuran, juga jenis yang beragam. MASS mulai dimanfaatkan untuk banyak kepentingan, mulai dari penggunaan untuk keperluan oceanografi, penelitian ilmiah, kebutuhan transportasi, hingga untuk keperluan pemantauan lingkungan. Selain efisiensi daya ketahanannya yang mampu mencapai lebih dari hitungan bulan - dalam beberapa pengembangan teknologi MASS sudah menggunakan panel/tenaga surya, tenaga angin, dan generator diesel - salah satu bentuk kemajuan teknologi yang ditawarkan MASS dalam membantu manusia adalah dapat memberikan informasi realtime dari suatu medan yang dapat membahayakan keselamatan manusia dengan tanpa mengandalkan tenaga manusia itu sendiri secara langsung. MASS juga diklaim sangat dapat mengurangi beban bahan bakar hingga 95\% dan efisiensi badan kapal dengan pengurangan ruang untuk manusia seperti dapur juga toilet. $^{1}$

Pada dasarnya, dalam hal ini teknologi berupa otomatisasi dapat dipahami sebagai kinerja yang dilakukan oleh sebuah mesin yang dibagi menjadi mesin yang masih dalam kendali manusia maupun yang berkerja secara mandiri tanpa campur tangan manusia. Fitur utama yang pastinya dimiliki oleh otomatisasi atau sistem yang otomatis adalah adanya kendali jarak jauh dari kapal yang dioperasikan secara otomatis (kendali dilakukan oleh manusia dari jarak jauh). ${ }^{2}$

Teknologi MASS sebenarnya telah lama digunakan misalnya dalam kegiatan operasi militer selama lebih dari 60 tahun. Teknologi yang digunakan antara lain meliputi torpedo, rudal jelajah, satelit, dan lain sebagainya. Selain untuk penggunaan operasi militer, MASS juga telah dilibatkan pada ranah kebutuhan sipil. Pemanfaatannya antara lain untuk

\footnotetext{
${ }^{1}$ Faustro Ferreira. (2019). "Regulatory and Liability Issues of Autonomous Surface Vehicles". Tesis. Italia: Department of Political Sciences Universita Di Pisa, h. 1.

2 Henrik Ringbom. (2019). "Regulating Autonomous Ships-Concepts, Challenges and Precedents". Ocean Development \& International Law. 50:2-3, h. 142-143. doi: 10.1080/00908320.2019.1582593.
}

pekerjaan dan pengukuran di lingkungan radioaktif, oleh berbagai industri lepas pantai untuk menciptakan dan memelihara fasilitas bawah laut, untuk penelitian atmosfer dan bawah laut, dan kebutuhan lainnya. ${ }^{3}$

Uji coba MASS pada masa Perang Dunia ke II, telah banyak dikembangkan juga, misalnya Kanada yang terlebih dahulu sudah mengembangkan sebuah konsep yakni Torpedo COMOX sebelum melakukan serangan ke Normandia. Pada masa penyerangan tersebut, MASS sengaja di desain sebagai pengganti pesawat untuk mengeluarkan asap. Kemudian MASS berkembang menjadi lebih canggih setelah masa Perang Dunia ke II berakhir. ${ }^{4}$

Perkembangan tersebut diantaranya adalah penggunaan MASS untuk mengambil sample air yang terkontaminasi unsur zat radioaktif pasca serangkaian uji coba nuklir (operasi untuk menguji pengaruh senjata nuklir terhadap kapal angkatan laut dengan meledakkan sebanyak \pm 23 kiloton bom yang dinamakan Baker) yang dilakukan oleh Amerika Serikat pada Tahun 1946 di bawah laut wilayah Bikini Atol, Samudera Pasifik, atau yang mana kegiatan tersebut dikenal juga dengan nama Operasi Crossroads. ${ }^{5}$ Bahkan saat ini Kapal Nirawak The Sea Hunter Anti-Submarine Warfare Continuous Trail Unmanned Vessel (Sea Hunter ACTUV) yang dikembangkan dan dibangun oleh Defense Advanced Research Projects Agency (DARPA) untuk Angkatan Laut Amerika Serikat (Naval) yang diluncurkan pada Tahun 2016 ini, dapat beroperasi secara otomatis/ mandiri dengan kendali jarak jauh sesuai dengan kebutuhan $^{6}$ dan memiliki misi khusus yakni untuk menangani pertempuran di laut dan anti kapal-selam (dapat bertindak sebagai kapal mata-mata). ${ }^{7}$

\footnotetext{
${ }^{3}$ National Research Council, Division on Engineering and Physical Sciences. (2005). Autonomous Vehicles in Support of Naval Operations. Washington DC: National Academies Press, h. 1.

${ }^{4}$ Ni Made Rai Ratih C. Perbani dan Deni Suwardhi. (2014). "Pembangunan Sistem Penentuan Posisi dan Navigasi Berbasiskan Sistem Unmanned Surface Vehicle (USV) untuk Survei Batimetri”. Jurnal Itenas Rekayasa. Vol. 01 (18), h. 10.

${ }^{5}$ https://www.bikiniatoll.com/, diakses pada 22-03-2020.

${ }^{6}$ https://www.naval-technology.com/projects/sea-hunterasw-continuous-trail-unmanned-vessel-actuv/, diakses pada 16-08-2021.

${ }^{7}$ https://tekno.tempo.co/read/1062249/sea-hunter-actuvkapal-nirawak-canggih-amerika-simak-videonya/full\&view $=o k$, diakses pada 16-08-2021.
} 
Ragam perkembangan teknologi yang ditawarkan MASS sampai saat ini belum diiringi dengan perkembangan hukum yang mengaturnya, misalnya mengenai pengaturan aspek keselamatan dalam pengoperasian MASS. MASS masih kerap dianggap sebagai teknologi yang sangat baru dan dapat dikatakan masih dalam tahap pengembangan. belum tersedianyaregulasi yang secara khusus mengatur megenai MASS bukan tidak mungkin tanpa resiko. Padahal, regulasi khusus sangat dibutuhkan dalam mencegah penyalahgunaan oleh pihak yang tidak bertanggungjawab atas penggunaan teknologi MASS yang semakin pesat dan mungkin menyimpan potensi bahaya.

Indonesia sebagai negara kepulauan yang memiliki laut yang begitu luas pun sempat menyampaikan intervensi berupa masukan pada peserta sidang Maritime Safety Committee (MSC) ke-98 berdasarkan pengalaman selama kurun waktu lima bulan terdapat lebih dari 10 kali insiden kapal kandas yang merusak terumbu karang, misalnya yang terjadi di Raja Ampat, Papua Barat (padahal kapal dikomandoi langsung oleh manusia/nahkoda). Nilai gugatan atas kerugian yang ditimbulkan akibat insiden tersebut sangat besar karena nilai perhitungan kerusakan lingkungan khususnya rehabilitasi terumbu karang yang tinggi. Maka berdasarkan pengalaman buruk tersebut perlu adanya regulasi yang clear mengenai teknologi MASS, misalnya pengaturan mengenai hal teknis tertentu terhadap potensi insiden atau resiko atas pengoperasian kapal dari jarak jauh. ${ }^{8}$ Hal ini perlu dilakukan sebagai salah satu bentuk tindakan preventif apabila suatu hari nanti terjadi suatu insiden yang melibatkan MASS. Berdasarkan case ini, perlu adanya upaya preventif berupa regulasi khusus atau pengaturan yang spesifik terhadap MASS, misalnya mengenai pertanggungjawaban atas insiden yang terjadi dalam pengoperasiannya yang tidak dikomandoi secara langsung oleh manusia.

\section{PERUMUSAN MASALAH}

Urgensi penyusunan regulasi MASS dan pedoman pengoperasian pra-penetapan regulasi formal.

${ }^{8}$ https://maritim.go.id/indonesia-usul-aturan-khusus-untukkapal-laut-tanpa-awak-di-sidang-imo/, diakses pada 16-08-2021.

\section{METODE PENELITIAN}

Metode penelitian yang digunakan adalah metode penelitian hukum normatif dengan pendekatan perundang-undangan (statute approach) untuk mengisi kekosongan hukum positif dan pendekatan konsep (conceptual approach) untuk merefleksikan fenomena baru yang diabstraksikan dari hal yang partikular. ${ }^{9}$ Metode penelitian dengan pendekatan perundang-undangan akan meneliti berbagai aturan hukum yang secara langsung maupun tidak langsung terkait dan menjadi poin utama suatu penelitian tertentu. Metode ini akan mengimplikasikan hukum sebagai suatu sistem atau pola yang bersifat komprehensif, inklusif, dan sistematis. Metode pendekatan perundang-undangan ini akan dileburkan dengan metode pendekatan konsep yang akan meneliti hal-hal menonjol dari perspektif yang praktis. Bahan penelitian akan direfleksikan berdasarkan norma hukum yang ada dan berdasarkan suatu fenomena penting dengan sudut pandang yang praktis. Sifat penelitian bersifat eksploratif yang bertujuan untuk memperdalam pengetahuan/melahirkan ide baru dengan memperdalam ilmu pengetahuan atas suatu fenomena (yang relatif baru $)^{10}$ terkait dengan perkembangan hukum MASS. Penelitian eksploratif merupakan suatu penelitian permulaan/perdana yang dapat mengawali penelitian lanjutan lainnya.

\section{PEMBAHASAN}

Definisi MASS setidaknya dapat dimaknai lewat sebuah pendapat bahwa "The term USV refers to any vehicle that operates on the surface of the water without a crew". ${ }^{11}$ Dapat dipahami bahwa MASS merupakan sebuah wahana permukaan air - biasanya berupa kapal di atas permukaan laut_yang mampu beroperasi secara otomatis/otonom lepas dari komando atau kendali manusia secara langsung (tanpa awak). MASS beroperasi otomatis melalui Ground Control Station (GCS) secara

\footnotetext{
${ }^{9}$ Johnny Ibrahim. (2007). Teori dan Metodologi Penelitian Hukum Normatif. Malang: Bayumedia Publishing, h. 302-306.

${ }^{10}$ Nomensen Sinamo. (2009). Metode Penelitian Hukum. Jakarta: Bumi Intitama Sejahtera, h. 33-34.

${ }^{11}$ Ru-jian Yan, Shuo Pang, Han-bing Sun \& Yong-jie Pang. (2010). "Development and Missions of Unmanned Surface Vehicle". Journal of Marine Science and Application. 9, 451457. doi: https://doi.org/10.1007/s11804-010-1033-2
} 
realtime dengan elemetri manual maupun dengan memasukkan waypoint/lokasi tujuan. ${ }^{12}$

Majunya teknologi di dunia perkalapalan dengan MASS sebagai warna yang dianggap baru dalam dunia pelayaran sangatlah pesat. MASS sudah banyak dikembangkan, baik oleh suatu negara dengan tujuan menjaga keamanan wilayah khususnya laut, maupun dikembangkan dengan tujuan komersil oleh perusahaan-perusahaan besar kelas dunia. Keunggulan atau terobosan yang ditawarkan MASS menang sangat menggiurkan dan tentunya menarik bagi banyak sekali peneliti di bidang teknologi. Peneliti, baik dari negara maupun perusahaan saling berlomba-lomba untuk menciptakan MASS yang paling mutakhir dan modern. Namun, segala bentuk perkembangan ini belum didukung sepenuhnya dengan regulasi yang mengikat bagi segala bentuk pengoperasian MASS. Terlebih, sampai dengan saat ini aturan-aturan terkait dengan laut yang berada di bawah United Nations Convention on The Law of The Sea 1982 (UNCLOS) belum ada yang secara khusus mengatur mengenai MASS. Meski beberapa diantaranya dapat dijadikan refleksi atau pedoman dalam penggunaan MASS, namun hal tersebut masih dirasa belum cukup karena perlu adanya penyesuaian terhadap fakta empiris MASS yang terus berkembang, mengingat MASS merupakan teknologi yang tergolong baru dan belum pernah diatur sebelumnya.

Padahal jika kita melihat pada sisi kecanggihan MASS, dapatlah diasumsikan bahwa terdapat banyak aspek yang harus diatur dalam kegiatan pengoperasiannya. Perlindungan lingkungan, keselamatan manusia, dan potensi penyalahgunaan untuk itikad buruk merupakan beberapa contoh aspek yang harus dianulir sebagai suatu rules dalam kegiatan pengoperasian MASS.

Dapat disimpulkan bahwa urgensi penyusunan regulasi MASS terletak pada kekosongan hukum dari segi pembuatannya sampai dengan pengoperasiannya yang sampai dengan saat ini masih dipertanyakan. Jika MASS dianalogikan dengan kapal yang dioperasikan secara konvensional atau kapal dengan awak, maka beberapa regulasi yang mengatur mengenai

12 Fajar Ramadhan dan Wasis Dwi Aryawan (2017). "Pembuatan Detail Desain Unmanned Surface Vehicle (USV) untuk Monitoring Wilayah Perairan Indonesia”. Jurnal Teknik ITS. 2 (6), 310. kapal konvensional tersebut akan sangat mungkin diterapkan dan diimplementasikan dalam penyusunan regulasi MASS. Tentunya regulasi yang telah ada tersebut harus disesuaikan dan banyak ditambah mengingat MASS merupakan kapal yang dilengkapi teknologi yang berbeda dengan kapal konvensional. Misalnya, dampak pengoperasian, emisi dan aspek keselamatannya juga akan berbeda. Regulasi MASS juga harus tunduk pada beberapa aspek penting misalnya kewajiban kelayakan operasi di laut, keselamatan kerja, dan tanggung jawab operator kapal. Sebagai contoh, terdapat peran manusia dalam pegoperasian kapal konvensional yang akan digantikan oleh teknologi MASS yang akan sangat mungkin lebih unggul. Pelimpahan wewenang dari manusia pada teknologi MASS ini akan menuntut kejelasan aspek pertanggungjawaban. Maka, dari beberapa isu tersebut, sudahlah sangat jelas bahwa MASS perlu memiliki regulasi yang konkret. Secara umum, MASS harus dapat menyesuaikan diri dengan existing regulation dan segala aspek kebaruan atau kemajuan yang ditawarkannya secara layak dan sesuai dengan norma hukum laut lainnya. ${ }^{13}$

Pada Tahun 2017, sejumlah Negara anggota dalam IMO's Maritime Safety Committee (MSC) telah mengajukan proposal pembahasan terkait dengan MASS. Proposal tersebut kemudian telah dimasukan dalam agenda rapat selanjutnya untuk segera dibahas. Agenda ini direncanakan akan segera terealisasi untuk menentukan bagaimana kegiatan MASS yang aman dan ramah lingkungan dalam lingkup instrument International Maritime Organization (IMO). MSC juga mengakui bahwa IMO harus segera memiliki sikap yang pro-aktif dan dapat menjadi leading role, mengingat teknologi kapal yang tanpa awak mulai coba dioperasikan secara komersil dan terus berkembang dengan cepat. Kendati begitu, MASS yang beroperasi saat ini masih dalam tahap/masa percobaan di beberapa wilayah laut. ${ }^{14}$

IMO pada tahun yang sama, mulai membahas pengaturan MASS bersama dengan MSC yang kemudian menghasilkan pendapat bahwa diperlukan

${ }^{13}$ Luci Carey. (2017). "All Hands Off Deck? The Legal Barriers to Autonomous Ships". NUS Centre for Maritime Law Working Paper, h. 2.

${ }^{14}$ http://www.imo.org/en/MediaCentre/HotTopics/Pages/ Autonomous-shipping.aspx, diakses pada 22-03-2020. 
adanya perubahan dalam beberapa instrumen IMO yang perlu dituangkan menjadi sebuah regulasi untuk menunjang segi keselamatan operasi MASS. Organisasi internasional terkait lainnya seperti Comité Maritime International (CMI) juga mulai menggodok kebutuhan regulasi MASS di mana. Berdasarkan hasil analisa CMI, dapat disimpulkan bahwa tidak mungkin regulasi MASS hanya disusun dengan 'transplantasi' secara mutlak dari existing regulation tentang pertanggungjawaban kapal dengan awak (kapal konvensional). Diperlukan peninjauan yang lebih komprehensif dari kerangka kerja yang sudah ada saat ini (dari konvensi-konvensi dan aturan lainnya terkait kapal), termasuk juga mendengar pendapat yang dibuka secara luas dari pihak terkait. Hal yang perlu ditinjau misalnya mengenai pendaftaran, klasifikasi, keselamatan, pertanggungjawaban, dan asuransi. ${ }^{15}$

MSC kemudian menetapkan kerangka kerja dan metodologi atas penyusunan regulasi MASS pada akhir Tahun 2018 yang ditargetkan akan rampung pada Tahun 2020. Kerangka kerja dan metodologi tersebut setidaknya harus sesuai dengan konvensi yang pada dasarnya mengasumsikan bahwa kapal dikendalikan secara langsung oleh manusia atau tidak dijalankan secara otomatis. ${ }^{16}$

Kemajuan yang telah dilakukan MSC dalam penyusunan regulasi MASS antara lain adalah melakukan identifikasi dan inventarisasi ketentuan IMO yang dapat/atau harus dijadikan referensi jugamelakukan analisis untuk menentukan dan memberikan pertimbangan dalam pengoperasian MASS. Penyusunan regulasi MASS akan meninjau dan merujuk existing regulation yang ditetapkan oleh badan internal IMO, yang setidak-tidaknya mencakup: ${ }^{17}$

- MSC: 1. Safety of Life at Sea 1960 (SOLAS);

2. International Regulations for Preventing Collision at Sea 1972/Collision Regulation (COLREG); 3. Loading and Stability (Load Lines); 4. Standards of Training, Certification and Watchkeeping for Fishing Vessel Personnel

\footnotetext{
${ }^{15}$ Faustro Ferreira. (2019). Regulatory and Liability Issues of Autonomous Surface Vehicles, h. 2-5.

${ }^{16}$ https://jurnalmaritim.com/sekilas-regulasi-mass-marineautonomous-surface-ships-atau-kapal-tanpa-awak/, diakses pada 22-03-2020.

17 http://www.imo.org/en/MediaCentre/HotTopics/Pages/ Autonomous-shipping.aspx, diakses pada 23-03-2020.
}

1995 (SCTW-F); 5. Search and Rescue (SAR);

6. Tonnage Measurement (Tonnage Convention);

7. Safe Containers (CSC); 8. Special Trade Passenger Ship Instruments (SPACE STP, STP);

9. dan konvensi terkait lainnya.

- Facilitation Complete: Convention on Facilitation of International Maritime Traffic (FAL Convention).

- Legal Commite: 1. Conventions under the purview of the Legal Committee; 2. Conventions emanating from the Legal Committee, with shared cognizance with other IMO committees; 3. Joint treaties with IMO and other UN bodies, emanating from the Legal Committee.

Pada pertengahan Tahun 2019, MSC menetapkan Keputusan Nomor MSC.1/Circ.1604 yang merupakan Pedoman atau Panduan Sementara uji coba MASS. MSC sepakat untuk mentaati panduan sementara tersebut yang mana tujuan utama dari penerbitan panduan tersebut adalah untuk membantu otoritas dan stakeholders' terkait — ketika merencanakan, mengizinkan, dan melakukan - dalam memastikan bahwa uji coba sistem dan infrastruktur yang terkait dengan MASS dilakukan dengan aman dan juga memperhatikan perlindungan lingkungan. MSC menjadikan panduan tersebut sebagai sebuah himbauan kepada negara anggota dan organisasi internasional untuk dapat menggunakannya dan menjadi perhatian bersama. ${ }^{18}$

Pedoman Sementara tersebut mengatur hal-hal sebagai berikut: 1 . Risk management; 2. Compliance with mandatory instruments; 3. Manning and qualifications of personnel involved in MASS trials; 4. Human element (including monitoring infrastructure and human-system interface); 5. Infrastructure for safe conduct of trials; 6. Trial awareness; 7. Communications and data exchange; 8. Reporting requirements and information sharing; 9. Scope and objective for each individual trial; 10. Cyber risk management.

Pedoman ini dianjurkan agar dapat digunakan ketika melakukan uji coba sistem dan infrastruktur MASS untuk mengevaluasi metode alternatif dalam melakukan fungsi tertentu untuk memenuhi persyaratan peraturan yang ditentukan oleh berbagai instrument IMO. Kewajiban dan tanggung jawab

${ }^{18}$ http://www.imo.org/en/MediaCentre/HotTopics/Pages/ Autonomous-shipping.aspx, diakses pada 23-03-2020. 
pihak yang terlibat ditetapkan oleh masing-masing instrument yang terkait, di mana tanggung jawab atas kegiatan uji coba diberikan berdasarkan izin suatu negara (otoritas tertentu dari negara terkait). Resiko yang terkait dengan kegiatan uji coba juga harus diidentifikasi setiap langkahnya secara tepat untuk mengurangi resiko atau meminimalisir resiko ke level yang dapat dipraktikkan dan dapat diterima secara wajar. Selain itu, setiap langkah harus diambil secara tepat dalam memastikan jenis dan bentuk sistem infrastruktur yang digunakan saat melakukan uji coba MASS memenuhi manajemen resiko cyber.

Bila merujuk pada teori hukum yang dipandang sebagai suatu alat keseimbangan kepentingan sebagaimana yang dikemukakan oleh Roscoe Pond, maka kiranya perlu menghindari konstruksi hukum yang secara tidak langsung terlihat abstrak. Hukum tidak boleh digunakan dengan sudut pandang yang "mengawang" dan harus dibuat nyata dalam makna yang konkret sesuai dengan kebutuhan dan kepentingan empiris. Untuk menciptakan suatu hal yang adil, maka perlu menata hukum dengan seimbang dan proporsional sesuai dengan teori law as a tool of social engineering, yang dapat disimpulkan secara sederhana bahwa suatu hukum akan menata kepentingan dalam tatanan masyarakat. ${ }^{19}$ Maka meskipun terdapat beberapa ketentuan di bawah UNCLOS yang dapat dikorelasikan dengan kebutuhan MASS dan adanya pedoman sementara, namun ketentuan khusus mengenai MASS belum tersedia dan dapat diasumsikan bahwa berdasarkan teori keseimbangan kepentingan dan teori law as a tool of social engineering bahwa hukum yang terkait dengan MASS masih "mengawang” dan belum tertata.

Berdasarkan Pedoman Sementara tersebut, untuk memudahkan identifikasi segala aspek yang perlu dimasukkan dalam penyusunan regulasi MASS, MSC kemudian membagi klasifikasi MASS ke dalam empat tingkat identifikasi, antara lain: ${ }^{20}$

Pertama, Tingkatan Pertama, kapal yang masih dioperasikan secara langsung oleh awak kapal namun

\footnotetext{
${ }^{19}$ Satjipto Raharjo. (2013). Teori Hukum; Strategi Tertib Manusia Lintas Ruang dan Generasi. Yogyakarta: Genta Publishing, h. 139-140, lihat juga D. Liyod (ed). (1965). Introduction to Jurispridence. London: Stencens yang dikutip dari Contemporary Jurisdic Theory dari Roscoe Pond.

${ }^{20}$ http://www.imo.org/en/MediaCentre/HotTopics/Pages/ Autonomous-shipping.aspx, diakses pada 23-03-2020.
}

sebagian proses operasi dan juga sebagian fungsinya dapat bekerja secara otomatis dan dapat berjalan tanpa diperlukannya pengawasan secara penuh dan terus-menerus oleh awak kapal;

Kedua, Tingkatan Kedua, di mana awak kapal berada di atas kapal untuk mengendalikan dan mengoperasikan sistem dan fungsi kapal, namun secara bersamaan kapal secara otomatis dikendalikan dan juga dioperasikan dari lokasi lain;

Ketiga, Tingkatan Ketiga, kapal yang dikendalikan dan dioperasikan dari lokasi lain dengan tanpa awak kapal di atasnya;

Keempat, Tingkatan Keempat, kapal yang dilengkapi dengan sistem operasi untuk dapat membuat keputusan dan menentukan tindakannya sendiri tanpa adanya campur tangan manusia.

Selain empat tingkatan tersebut, terdapat juga beberapa hal yang harus dipertimbangkan dalam menganalisis dan menentukan cara yang paling tepat yang perlu dimasukkan dalam penyusunan regulasi MASS, antara lain: ${ }^{21} 1$. Kesetaraan, sebagaimana yang ditentukan oleh instrumen atau interpretasi yang berkembang; dan/atau 2. Mengubah instrumen yang ada; dan/atau 3. Mengembangkan instrumen baru; atau 4. Bukan berasal dari analisis tunggal.

Selain existing regulation yang akan dirujuk tersebut, sudah tentu penyusunan regulasi MASS harus tetap merujuk kepadaUNCLOS sebagai dasar umum dan regulasi utama dalam Hukum Laut. Poin yang diadopsi terutama terkait soal aktifitas perkapalan di laut yang mana kapal konvensional/ dengan awak dapat dianalogikan sebagai Kapal Nirawak/MASS. Misalnya sebagaimana yang diatur dalam article 19 yang terkait dengan aktifitas lintas damai di mana lintas damai (dalam kegiatan uji coba MASS) boleh dilakukan sepanjang tidak merugikan kedamaian, ketertiban, dan keamanan negara pantai yang dilewatinya. Kemudian, Article 20 yang mengatur mengenai kapal selam dan kendaraan bawah air, di mana kapal (dalam hal ini MASS yang beroperasi di bawah air) harus tetap melakukan navigasi di atas permukaan air dan tetap menunjukan bendera negaranya.

MASS yang saat ini secara umum dianggap masih dalam tahap pengembangan, setidaknya mendapatkan legalitas yang bebas dan mutlak jika

${ }^{21}$ http://www.imo.org/en/MediaCentre/HotTopics/Pages/ Autonomous-shipping.aspx, diakses pada 23-03-2020. 
kegiatan pengembangan tersebut dianalogikan sebagai kegiatan riset ilmiah kelautan dengan mengindahkan Bagian XIII UNCLOS tentang Marine Scientific Research. Sebagaimana yang diatur dalam article 238 mengenai Right to conduct marine scientific research, yang dapat dipahami bahwa semua negara (pihak terkait) memiliki hak untuk melakukan kegiatan riset ilmiah kelautan dengan tetap memperhatikan hak dan kewajiban negara lainnya dengan tetap mengindahkan seluruh ketentuan yang diatur di dalam UNCLOS. Kemudian, berdasarkan article 240 diatur bahwa penyelenggaraan riset ilmiah kelautan tunduk pada asas-asas umum yakni: (a) harus dilaksanakan semata-mata untuk tujuan damai; (b) harus dilakukan dengan metode ilmiah yang tepat dan dengan cara yang sesuai dengan UNCLOS; (c) tidak mengganggu secara tidak sah penggunaan laut lainnya yang sah sesuai dengan UNCLOS dan menghormati penggunaan laut yang dimaksud; (d) harus diselenggarakan sesuai dengan segala peraturan relevan yang diterima UNCLOS termasuk ketentuanketentuan mengenai perlindungan dan pelestarian lingkungan laut.

Namun, sebagaimana yang ditentukan dalam Article 241 bahwa legalitas kegiatan riset ilmiah kelautan tersebut tidak dapat dijadikan dasar hukum terhadap tuntutan atas lingkungan atau kekayaan alam. Berdasarkan Article 235, aspek pertanggungjawaban atas tuntutan yang lahir dari uji coba atau segala kegiatan MASS — jika dianalogikan sebagai riset ilmiah kelautan — melekat pada negara ataupun organisasi internasional yang kompeten (atas nama penggagas/penyelenggara).

Berdasarkan Article 235 tanggung jawab dapat ditafsirkan sebagai prestasi yang diemban oleh negara maupun pihak pemilik (misalnya uji coba dioperasikan oleh pihak non pemerintah) yang dilihat berdasarkan tujuan penggunaannya, kapal publik maupun kapal non publik. ${ }^{22}$ Pertanggungjawaban akan tunduk pada UNCLOS yang meskipun belum diratifikasi oleh semua negara, namun secara umum saat ini dapat diterima sebagai international customary law. Pertanggungjawaban ini juga mengacu pada identitas resmi kapal dimana berdasarkan Article 94 yang menentukan bahwa

\footnotetext{
22 Boer Mauna. (2011). Hukum Internasioal; Pengertian Peranan dan Fungsi Dalam Era Dinamika Global. Bandung: Alumni, h. 320.
}

kapal harus berlayar di bawah bendera suatu negara (kecuali dalam keadaan tertentu yang diatur dalam UNCLOS maupun perjanjian internasional).

Proses penyusunan regulasi MASS juga harus tetap merujuk existing regulationterkait lainnya seperti The International Convention for the Prevention of Pollution from Ships/Marine Pollution 1973/1978 (MARPOL). Perkembangan MASS secara implisit erat kaitannya dengan perkembangan ekonomi, namun harus tetap selaras dengan pelestarian lingkungan dan harus selalu berpedoman pada prinsip sustainable development yang mana unsur utamanya meliputi dimensi ekonomi, ekologi, dan sosial. ${ }^{23}$

Salah satu existing regulation sebagaimana yang dijadikan rujukan oleh MSC, setidaknya dapat ditemukan dalam The International Regulations for Preventing Collisions at Sea 1972 (COLREG) pengaturan secara eksplisit dan implisit mengenai MASS. Di mana COLREG berlaku untuk semua kapal yang ada di laut, digunakan atau dapat digunakan sebagai alat transportasi di atas air, maka MASS (dalam hal ini, namun dapat diaplikasikan juga diluar cargo purposes) yang ada di laut akan terikat dan tunduk untuk mematuhi COLREG. Aspek tanggung jawab pengoperasian MASS berada pada kapal itu sendiri karena pada dasarnya COLREG mengasumsikan bahwa kapal dioperasikan secara konvensional dengan awak kapal. ${ }^{24}$

Terkait dengan awak kapal, Maritime Labour Convention 2016 (MLC) setidaknya dapat mengisi kekosongan substansi mengenai siapakah yang dimaksud dengan awak kapal, Article II (f) MLC menyatakan bahwa "Seafarer means any person who is employed or engaged or works in any capacity on board a ship to which the Convention applies". Dapat diasumsikan bahwa awak kapal merupakan setiap orang yang bekerja dan memiliki keterkaitan dengan pengoperasian kapal, baik yang secara langsung maupun jarak jauh, merupakan pihak yang terlibat dalam pengoperasian MASS dan dianggap sebagai awak kapal. Sebagaimana yang juga ditentukan

23 Dina Sunyowati. (2010). “Tata Kelola Kelautan Berdasarkan Integrated Coastal and Ocean Management untuk Pembangunan Kelautan Berkelanjutan”. Jurnal Perspektif. Vol. 15 No. 1, h. 90.

${ }^{24}$ Luci Carey. (2017). "All Hands-Off Deck? The Legal Barriers to Autonomous Ships". NUS Centre for Maritime Law Working Paper, h. 10-11. 
dalam article 94 UNCLOS bahwa setiap awak kapal harus memenuhi kualifikasi yang dipersyaratkan (berpengalaman). ${ }^{25}$ Ketentuan mengenai awak kapal ini sudah diadopsi dalam Pedoman Sementara yang terhimpun dalam poin Manning and qualifications of personnel involved in MASS trials.

Existing regulation setidaknya mampu menganulir beberapa hal yang dapat dikaitkan atau dianalogikan antara kapal konvensional dengan MASS. Baik dari segi pembuatannya, perizinan, pengaplikasian, bahkan sampai dengan pengoperasiannya. Namun, hal ini tidak bisa menjadi sebuah keringanan bagi pihak yang berwenang yakni IMO dan juga MSC untuk menunda penyelesaian penyusunan regulasi MASS mengingat Pedoman Sementara yang sudah diterbitkan pada dasarnya hanyalah merupakan panduan yang jika dipahami tidak bersifat mengikat dan hanya menjadi sebuah acuan yang dianjurkan untuk diterapkan dalam setiap kegiatan yang berkaitan dengan MASS.

\section{PENUTUP}

\section{Kesimpulan}

Sampai dengan saat ini, MASS yang merupakan suatu kemajuan besar di bidang teknologi perkapalan dan sangat membantu untuk memenuhi kebutuhan manusia dalam memenuhi tuntutan zaman, belum memiliki regulasi yang sah dan konkret. Meskipun banyak sekali aspek yang secara khusus berbeda, namun secara umum dan pada prinsipnya MASS dapat dianalogikan sama dengan kapal konvensional di mana pada esensinya, MASS dan kapal konvensional merupakan moda atau wahana air. Berdasarkan kesamaan tersebut, saat ini setidaknya IMO lewat MSC sudah membuat sebuah regulasi yang dapat menjadi guidelines berupa Pedoman Sementara Nomor MSC.1/Circ.1604. Pedoman Sementara tersebut disusun untuk mengakomodir dan mengatur segala hal yang penting dalam kegiatan uji coba MASS dan diperuntukan bagi pihak-pihak yang berkepentingan. Selain Pedoman Sementara tersebut, pihak yang berkepentingan atau pihak lainnya yang terkait dalam pengembangan dan uji coba MASS,

${ }^{25}$ Thanasis Karlis. (2018). "Maritime Law Issues Related to The Operation of Unmanned Autonomous Cargo Ships". WMU Journal of Maritime Affairs, h. 121-122. doi: https://doi. org/10.1007/s13437-018-0135-6 dianjurkan untuk tunduk pada semua existing rules mengenai laut dan kapal (kapal konvensional).

\section{Rekomendasi}

IMO sebagai suatu badan penting di bawah United Nations (PBB) dan didirikan untuk fokus pada segala aspek yang terkait dengan laut, memiliki kewenangan khusus dalam pemutakhiran suatu regulasi mengenai laut. Perkembangan MASS yang begitu pesat sudah selayaknya segera diimbangi dengan hadirnya regulasi yang mampu menangkal segala potensi dampak buruk yang mungkin timbul. Existing regulation khususnya yang terkait dengan laut, lingkungan, dan kapal dapat dimaksimalkan untuk menjadi dasar dan sebagai bahan pertimbangan yang disesuaikan dengan kebutuhan MASS.

\section{DAFTAR PUSTAKA}

\section{Peraturan Perundangan-undangan:}

United Nations Convention on The Law of the Sea 1982 (UNCLOS).

Interim Guidelines for Mass Trials dari The Maritime Safety Committee (MSC), sesi ke 101, Juni 2019 Number: MSC.1/Circ.1604.

The International Regulations for Preventing Collisions at Sea 1972 (COLREG).

Maritime Labour Convention 2016 (MLC).

\section{Buku:}

Boer Mauna. (2011). Hukum Internasioal; Pengertian Peranan dan Fungsi Dalam Era Dinamika Global. Bandung: Alumni.

D. Liyod (ed). (1965). Introduction to Jurispridence. London: Stencens.

Johnny Ibrahim. (2007). Teori dan Metodologi Penelitian Hukum Normatif. Malang: Bayumedia Publishing.

National Research Council, Division on Engineering and Physical Sciences. (2005). Autonomous Vehicles in Support of Naval Operations. Washington DC: National Academies Press.

Nomensen Sinamo. (2009). Metode Penelitian Hukum. Jakarta: Bumi Intitama Sejahtera.

Satjipto Raharjo. (2013). Teori Hukum; Strategi Tertib Manusia Lintas Ruang dan Generasi. Yogyakarta: Genta Publishing. 


\section{Jurnal:}

Dina Sunyowati. (2010). "Tata Kelola Kelautan Berdasarkan Integrated Coastal and Ocean Management untuk Pembangunan Kelautan Berkelanjutan". Jurnal Perspektif. Vol. 15 No. 1, h. 90.

Fajar Ramadhan dan Wasis Dwi Aryawan (2017). "Pembuatan Detail Desain Unmanned Surface Vehicle (USV) untuk Monitoring Wilayah Perairan Indonesia". Jurnal Teknik ITS. 2 (6), 310.

Henrik Ringbom. (2019). "Regulating Autonomous Ships-Concepts, Challenges and Precedents". Ocean Development \& International Law. 50:2-3, h. 142-143. doi: 10.1080/00908320.2019.1582593.

Ni Made Rai Ratih C. Perbani dan Deni Suwardhi. (2014). "Pembangunan Sistem Penentuan Posisi dan Navigasi Berbasiskan Sistem Unmanned Surface Vehicle (USV) untuk Survei Batimetri”. Jurnal Itenas Rekayasa. Vol. 01 (18), h. 10.

Ru-jian Yan, Shuo Pang, Han-bing Sun \& Yong-jie Pang. (2010). "Development and Missions of Unmanned Surface Vehicle". Journal of Marine Science and Application. 9, 451-457. doi: https:// doi.org/10.1007/s11804-010-1033-2

Thanasis Karlis. (2018). "Maritime Law Issues Related to The Operation of Unmanned Autonomous Cargo Ships". WMU Journal of Maritime Affairs, h. 121-122. doi: https://doi. org/10.1007/s13437-018-0135-6

\section{Tesis, Artikel, Website:}

Faustro Ferreira. (2019). "Regulatory and Liability Issues of Autonomous Surface Vehicles". Tesis. Italia: Department of Political Sciences Universita Di Pisa, h. 1.

Faustro Ferreira. (2019). Regulatory and Liability Issues of Autonomous Surface Vehicles, h. 2-5.

http://www.imo.org/en/MediaCentre/HotTopics/

Pages/Autonomous-shipping.aspx, diakses pada 22-03-2020.

https://jurnalmaritim.com/sekilas-regulasi-massmarine-autonomous-surface-ships-atau-kapaltanpa-awak/, diakses pada 22-03-2020.

https://maritim.go.id/indonesia-usul-aturan-khususuntuk-kapal-laut-tanpa-awak-di-sidang-imo/, diakses pada 16-08-2021.

https://tekno.tempo.co/read/1062249/sea-hunteractuv-kapal-nirawak-canggih-amerika-simakvideonya/full\&view $=o k$, diakses pada 16-082021.

https://www.bikiniatoll.com/, diakses pada 22-032020.

https://www.naval-technology.com/projects/seahunter-asw-continuous-trail-unmanned-vesselactuv/, diakses pada 16-08-2021.

Luci Carey. (2017). "All Hands Off Deck? The Legal Barriers to Autonomous Ships". NUS Centre for Maritime Law Working Paper. 